\title{
EXTENSION OF LNG TERMINAL IN ŚWINOUJŚCIE. CHALLENGES AND BENEFITS
}

\begin{abstract}
The purpose of this paper is to show what challenges and benefits are related to the extension of the LNG terminal. Further development of the facility is a result of the increasing demand for natural gas in Poland. The author describes investments which are part of the LNG terminal extension (development of the LNG regasification system, construction of an additional tank, expansion of the railway infrastructure and building of a new wharf). According to the author, the expansion of the gas terminal including the introduction of innovative solutions and improvements, may result in significant reduction of natural gas imports from Russia to Poland. The extended gas terminal, together with the existing Baltic Pipe and interconnectors, may not only decrease the amount of gas delivered from Russia, but after 2022 also lead to resigning from a new long-term gas contract with that country. Enlarged terminal with more capacity as well as the option to import gas from various directions, often based on long-term contracts, make creation of a gas hub in Poland more feasible.
\end{abstract}

Keywords: LNG terminal, Świnoujście, development, logistics.

\section{INTRODUCTION}

The creation of the LNG Gasport in Świnoujście should be considered as an important event which increases Poland's gas security. This LNG Gasport is a source of additional supplies of raw material from anywhere in the world. The investment contributes clearly to the diversification of natural gas supplies to Poland, being an alternative to the import of this raw material through pipelines, especially from Russia.

Soon after the construction of the Gasport in Świnoujście was completed, the decision was made to develop the terminal further, which is the most important part of the entire facility. According to the plans the extended Gasport should significantly increase its capacity, satisfying even half of Poland's demand for gas. This is crucial for the energy security of the state.

The purpose of this paper is to show what challenges and benefits are related to the extension of the LNG terminal. As part of the problem analysis following research questions need to be considered: what infrastructure should be created as a result of the development project and how will the extended Gasport increase the gas security of Poland.

The paper includes mainly description required to present the meaning and characteristics of the terminal's extension. Additionally, prognostic method which is crucial when

\footnotetext{
${ }^{1}$ Łukasz Wojcieszak, DSc PhD, Associate Prof., Kielce University of Technology, al. Tysiąclecia Państwa Polskiego 7, 25-314 Kielce; e-mail: lwojcieszak@tu.kielce.pl. ORCID: 0000-0002-9166-4464 .
} 
predicting the possible results of the extension, as well as the comparative method and the praxeological approach have been used.

\section{THE ROLE OF THE GASPORT}

Polish authorities have desired to diversify sources of natural gas supplies since years and the LNG Gasport in Świnouście is a way to achieve these aspirations. Poland has been dependent on gas import from the Russian Federation for decades, which wasn't a perfect situation as Russia as the main gas supplier could put pressure on the importer. Therefore, mainly in the first and second decade of the new century, Polish authorities searched for alternative sources of gas. Various contracts and investments, in particular Gasport in Świnoujście, enabled gas supplies to Poland from non-Russian directions. Having the LNG terminal Poland can purchase the required natural gas at competitive prices. Should the terminal be further developed, Poland could even resign from supplies of the Russian raw material which is sometimes the declared goal of Polish energy policy.

Natural gas is a strategic raw material in Poland and annual demand of the country for this energy source exceeds 17 billion $\mathrm{m}^{3}$ (Piszczatowska, Kadej, 2018). Gas extracted in Poland covers around $25 \%$ of its demand, hence the raw material is being imported from an increasing number of countries. The gas import grows as a consequence of the rapidly increasing demand of the Polish market - the consumption of this resource increased from 15 billion $\mathrm{m}^{3}$ in 2015 up to 17 billion $\mathrm{m}^{3}$ in 2017 (Konsumpcja gazu w Polsce rośnie..., http). In August 1993 Poland and Russia signed an important agreement on the construction of a gas pipeline system to send raw material to Western Europe as well as gas supplies to Poland. In 1996 the so-called Yamal contract was concluded on the import of Russian gas into Poland for the period of 25 years, which involved the construction of a gas pipeline crossing Poland from the East to the West. Another agreement concluded in October 2010 stipulates that Poland will annually buy 11 billion $\mathrm{m}^{3}$ of gas imported from Russia till 2022 (Wojcieszak, 2012). This strong dependence on Russian gas encouraged Poland to look for diversified sources and directions of gas supply resulting in alternative pipeline projects, interconnectors with neighboring countries, as well as the construction of a Gasport The latter investment started 2011, however the first gas carrier came in December 2015 only due to some delays with commissioning the facility.

Liquefied natural gas is transported by special tank ships to terminals, where the raw material goes through the regasification process (process of converting liquefied natural gas [LNG] back to natural gas). Afterwards, the raw material is distributed via pipelines to recipients. The LNG terminal in Świnoujście is a key investment increasing the gas security of Poland and enabling the import of gas from anywhere in the world. It is also a pioneering venture of that kind in Central and Eastern Europe as well as in the Baltic Sea region. According to the project of the investment, the LNG terminal should have a capacity to receive 5 billion $\mathrm{m}^{3}$ of LNG per year in the first phase. In the next stage, the regasification capacity is planned to increase up to 7.5 billion $\mathrm{m}^{3}$ (Świątkowska, 2013).

Poland imports LNG mainly from Qatar and the USA, which are the main LNG exporters in the world (next to Australia). The USA (Luciani, 2016) becomes the leader in this area with their key supplier, Cheniere Energy, which signed a long-term contract with Poland on LNG delivery. The contracts with American LNG exporters will provide PGNiG (Polskie Górnictwo Naftowe i Gazownictwo SA - the Polish state-controlled, largest oil and 
gas exploration and production company) with additional 7.3 billion $\mathrm{m}^{3}$ of gas after regasification for the period between 2012 and 2042 (Coraz więcej LNG zamiast gazu z Rosji..., http). The LNG terminal is an important part of the so-called North Gate, which facilitates the transmission of gas along the North-South line, and not from the East to the West as it has been for decades. Gas pipeline network which connects the Central and Eastern Europe will significantly increase the level of Poland's security, integrating at the same time the European gas transmission system. This is in line with the concept of the so-called Three Seas Initiative which encourages cooperation between countries located in the Baltic, Adriatic and the Black Sea region.

The Polish Gasport, before it is further developed, consists of an LNG terminal, a breakwater in the Baltic Sea and a connecting gas pipeline (about $6 \mathrm{~km}$ long) as well as a transmission pipeline (about $74 \mathrm{~km}$ long) - the latter connects the LNG terminal with the national transmission system (Kubiak, Janik, Szulc, 2016). The terminal is built on the Wolin Island, covers 48 ha and is situated 750 meters from the sea coast (Gałczyński, Zajdler, Ruszel, ed., 2017). The facility increases the scope of technological processes which can be managed there: upload LNG from a tanker at the unloading dock, LNG storage in tanks, LNG regasification, gas dispatch to the national transmission system and loading of LNG on tank trucks and ISO tank containers. The terminal has two cryogenic containers for LNG storage, which have capacity of 160 thousand $\mathrm{m}^{3}$ each (Terminal LNG $w$ Świnoujściu..., http).

According to Wojciech Jędrzejewski building of the terminal in Świnoujście and the subsequent increase of energy security may result in desecuritization of gas issues. Once this area is desecuritized it will be possible to look at the economic aspect of natural gas trade and consider economic profits rather than political benefits (Jędrzejewski, 2013). The LNG terminal, in particular after further development, will at the same time facilitate gas supply not only to Poland but also to other countries of Central and Eastern Europe. Over the years Poland has transmitted gas from the East to the West only, which was a weakness of the Polish gas pipeline network. The terminal can change this and introduce the NorthSouth transmission route. The development of gas transmission infrastructure impacts Polish-Russian relations. Since Poland reduced its dependence on the gas imports from Russia both energy as well as political relations between those countries can change (Księżopolski, 2013).

\section{REASONS FOR EXPANDING THE LNG TERMINAL}

Poland plans to expand the terminal to increase the security of its gas supply, as well as to adapt the facility to the requirements of the economy. Larger terminal is needed to satisfy growing market demand for imported gas. The terminal will be expanded by additional wharf, to make the port more flexible and able to serve as a LNG supply center for smaller Gasports that are being built and are planned to be built on the Baltic Sea. Increasing terminal's capacity to load LNG on truck and rail tank cars is part of the PGNiG strategy based on the so-called 'island gasification' to deliver gas to the places located far from the transmission network. According to the 'island gasification' concept regasification station and a local distribution network need to be built and the gas in liquefied form will be supplied to this station via LNG trucks or rail tank cars (Malinowski, 2018).

New functionalities and services based on LNG help to develop the natural gas market in Poland. The decision to extend the terminal was based on the results of the feasibility study from August 2017. According to the plans project will utilize EU funds from Opera- 
tional Programme 'Infrastructure and Environment'; extension of the terminal by another wharf is planned to be finalized in 2021 (Wspólnie na rzecz rozbudowy..., http) (the investment will be implemented according to 'design-build' method). Call for bids has been announced for key works related to the extension of the gas terminal in Świnoujście. Experts estimate the cost of the investment for one billion PLN (Malinowski, 2018).

The LNG terminal can currently store 5 billion $\mathrm{m}^{3}$ of gas, which is enough to cover $1 / 3$ of Poland's needs. Once the third tank ${ }^{2}$ is built, the terminal will have capacity to cumulate an amount of gas that will satisfy even half the demand of the country

The extension of this largest terminal on the Baltic Sea is part of a comprehensive development strategy of the Gaz-System group, gas transmission operator who finances this investment. The further development of the terminal is planned to be completed in 2022 (Rudnicki, 2017). Project works have already started, 2019 the construction works will commence (Gonera, 2018).

In November 2017 the Agreement was signed in the voivodeship office between representatives of the company Polskie LNG (Gaz-System Group) and the management of Szczecin and Świnoujście Seaports to build another wharf in the terminal. In result the parties will cooperate exchanging information and documentation related to the construction of the second wharf (Wspólnie na rzecz rozbudowy Terminalu LNG w Świnoujściu..., http).

\section{DEVELOPMENT PLANS}

The company Polskie LNG has published a periodic information to inform the market about proceedings planned in the nearest future aimed at finding a contractor for further development of the LNG terminal in Świnoujście (Polskie LNG przygotowuje proces przetargowy..., http). The extension of the terminal will increase its regasification and reloading capacity to ensure best utilization of the facility's potential and create good environment for market development in the coming years. Four projects are planned to extend the LNG terminal in Świnoujście:

1. SCV (Submerged Combustion Vaporizer) project - covers further development of the existing LNG regasification system based on two additional Submerged Combustion Vaporizers with a maximum vaporizing duty of approximately 328,000 $\mathrm{Nm}^{3} / \mathrm{h}$ gas as well as associated installations.

2. Tank - includes a new complete LNG full containment tank with a gross volume of $180,000 \mathrm{~m}^{3}$, with required equipment and installations enabling full service of the new tank and its cooperation with two existing tanks.

3. Railway project - covers building of a complete railway siding with turnouts and an access railroad with equipment required to operate the LNG rail loading facility for rail tank cars and ISO tank container, consisting of twelve LNG loading stations. This facility introduces new service of the terminal, enabling loading of liquefied gas into rail tank cars and ISO tank container on the land part of the port (Polskie $L N G$ przygotowuje proces przetargowy..., http).

4. Building of a new wharf in the Gasport along with the system to bunker and reload the LNG from tanks to ships. This is a sea-related part of the extension project which will be implemented independently to the other projects, in cooperation with the

\footnotetext{
${ }^{2}$ It was not certain for a long time if the third tank will be built at all (see M. Gałczyński, Zajdler,
} Ruszel, ed., 2017). 
management of Szczecin and Świnoujście Seaports (Rusza przetarg na rozbudowe terminalu..., http). New wharf will introduce additional services, i.e. loading and unloading of small- and medium-sized tankers, transshipment of LNG (from the ship at the unloading wharf to the ship at the trans-shipment wharf), loading of LNG bunkering vessels and natural gas bunkering (Januszek, 2018).

The project on the extension of the terminal was discussed in April 2018 during technical consultations - meetings to give the ordering party an opportunity to learn about the best solutions available on the market. Representatives of the construction companies took part in the meetings as well. The construction works assume a comprehensive execution of the project including project plan, design and construction (Ciepiela, 2018). In June 2018, parliamentary representatives from the Committee for Energy, Treasury and Environmental Protection, Natural Resources and Forestry promised to support the draft amendment to the act regarding the investment in the Gasport of Świnoujście. The existing legal solutions were considered insufficient and not permitting necessary investments to be made within the required timeframe to ensure stable and safe supply, as well as transmission of natural gas (Januszek, 2018).

\section{BENEFITS OF THE EXTENSION}

The amount of imported liquefied gas increased at the end of the second decade of the 21 st century. According to PGNiG, LNG volumes of gas import from Qatar, Norway and the USA increased then times faster than gas imports from Russia. The increase in LNG imports compared to gas delivered from Russia was higher. Between January and July 2018 PGNiG imported about 0.6 billion $\mathrm{cm}^{3}$ more LNG than in the same period in 2017. At the same time, gas imports from Russia in the period between January and July 2018 increased by less than 0.4 billion cubic meters compared to the same period of 2017 (which constitutes a growth of 6\%). The percentage of gas delivered from Russia dropped again to $75 \%$ of the whole gas imported by PGNiG between January and July 2018. At the same time LNG import maintained an upward trend and, in this period, increased by $6 \%$ to $19 \%$ of the whole import (Konsumpcja gazu w Polsce rośnie..., http).

PGNiG makes preparations to start supplying the Polish market with gas extracted in Norway, which would be sent via the Baltic Pipe (gas pipeline connecting Poland and Denmark) and is planned to begin end 2022. As a result of the long-term contracts which Poland negotiates with various countries, starting 2022 PGNiG will have an annual portfolio of over 4 million tones of LNG delivered from the USA (approximately 5.5 billion $\mathrm{m}^{3}$ of gas after regasification) (Konsumpcja gazu w Polsce rośnie..., http). PGNiG signed a long-term agreement to ensure LNG supplies from USA for the next 24 years - the contract guarantees deliveries of 0.7 billion $\mathrm{m}^{3}$ gas after regasification between 2019 and 2022 and around 39 billion $\mathrm{m}^{3}$ between 2023 and 2042. In October 2018 PGNiG concluded two long-term contracts for the supply of the liquefied gas. As part of each agreement the company will buy around 1 million tones of $\mathrm{LNG}$ (which makes about 1.35 billion $\mathrm{m}^{3}$ of the raw material after regasification) per year for the next 20 years. The gas is planned to be delivered through pipes which will be available in 2022 and 2023 the earliest, once the Yamal contract reaches its end. Poland seeks to conclude contracts for LNG supplies with gas producers from various parts of the world. In particular, the agreement signed with Qatar is crucial (with a significant annex from May 2017) (Jakóbik, 2018), but the potential import of raw material from other directions is also important. 
Currently the LNG-powered machines become more and more important, especially considering the low-emission standards. This is a stimulus to further increase the volume of LNG supplies as well as expand the gas distribution network. According to the president of Polski LNG, Paweł Jakubowski, the terminal in Świnoujście could become a gas hub in the Baltic Sea region. In the gas hub concept, the raw material could even be delivered to places where there is no traditional transmission infrastructure. The LNG fuel is used in maritime transport which constitutes another impulse to increase regasification capacity of the terminal. The Sulphur Directive forces companies to significantly reduce the amount of this element in fuels; therefore LNG - powered ships become a good, environment friendly, alternative for maritime transport (Prezes polskiego $L N G . .$. , http).

After extension of the terminal Poland will be able to import 50\% more LNG gas than before. When exploring new functionalities of the facility, prospects for the development of the LNG market not only in Poland but also in the Central and Eastern Europe will be taken into consideration. Moreover, the extension of the terminal which boosts its regasification capacity to $7.5 \mathrm{bcm}$, considerably increases the level of gas security in Poland. Using the current technological improvements in the LNG industry and implementing innovative solutions the Gaz-System company will be able to choose the most optimal path for the development of terminal's infrastructure and services, making full use of the market potential in the region at the same time (Furman, 2017).

Expansion of the terminal will result in an increased gas supply in Poland, which in turn will lead to price drop of this raw material for the final consumer. PGNiG reloads the imported LNG to tank trucks, delivers it to small regasification stations and from there the raw material is sent via gas pipelines, providing supplies on a particular area only. The company would like to use the additional quantities of LNG to supply industrial customers as well as deliver LNG to ships, cars and small LNG terminals in the Baltic Sea region. LNG from the Gasport in Świnoujście is transported by road tank trucks to Estonia, and is used there as fuel for ferries built in the Gdańsk shipyard (Furman, 2017).

\section{CONCLUSION}

The Gasport needs to be further developed to satisfy the growing demand for the raw material as well as accommodate the increase in gas imports to Świnoujście. The investment will follow the "design-build" method. The Gaspori in Swinoujście provides diversification of gas supplies to Poland, even before it got extended. The LNG imported to terminal can compete with gas delivered from Russia, which has dominated in the Polish market for years. The first years of the LNG Gasport's operation can therefore be considered as the time to reduce the dependence on one key supplier. At the same time, however, the amount of gas imported via the terminal is still relatively small compared to the volumes imported via pipelines, especially from the Russian Federation.

The conclusion after analysis of the first research question is that the expansion of the LNG terminal in Świnoujście should consists of four important investment. Further development of the regasification system, additional tank, expansion of the railway infrastructure as well as construction of a new wharf are significant initiatives that clearly increase the capacity of the facility. Considering the expected increase in the volume of imported gas, it is particularly important to establish a second LNG transshipment point, as well as to increase the regasification capacity of the terminal. After construction of another tank the facility will have more bandwidth. 
The analysis of the second research question confirms that expansion of the gas terminal may lead to a significant reduction of natural gas imports from the Russian Federation to Poland. When the Gasport is further developed, the Baltic Pipe is operational and other investments (in particular interconnectors) are implemented, theoretically it could be even possible to resign from the gas imports from Russia. Increased capacity of the gasport makes creation of a gas hub in Poland more likely. Furthermore, it is possible that Poland will significantly reduce the dependence on gas imported from Russia, in particular even resign from signing a new long-term gas contract with Russian Federation.

Further development of the Gasport will strengthen Poland's gas security. This is important because the demand for raw materials is growing both in Poland as well as in the Three Seas region. At the same time, after 2022 Poland will no longer be so heavily dependent on gas supplies from Russia as the existing contract may not be extended; this will create opportunity to buy more raw material from other directions. Particularly large amounts of gas are planned to come from the USA. The terminal, which gets extended in the early twenties of the $21^{\text {st }}$ century, can significantly contribute to the real diversification of gas supplies to Poland. In the future the Gasport can be further developed if required.

\section{REFERENCES}

Ciepiela, D., (2018). Rusza dialog techniczny ws. rozbudowy terminalu LNG. Gazownictwo. wnp.pl, 11.04.2018. [Access: 12.01.2019]. Access on the internet: https://gazownictwo.wnp.pl/ rusza-dialog-techniczny-ws-rozbudowy-terminalu-lng,321217_1_0_0.html.

Coraz więcej LNG zamiast gazu z Rosji. PGNiG podsumowuje 2018 rok. Biznesalert.pl, 09.01.2019 [Access: 5.02.2019]. Access on the internet: https://biznesalert.pl/polska-rosja-import-gazu-pgnig.

Furman, T. (2017). Terminal LNG będzie większy, Energia.rp.pl, 19.04.2017 [Access 13.12.2018]. Access on the internet:https://energia.rp.pl/surowce-i-paliwa/gaz/7902-terminallng-bedzie-wiekszy.

Gałczyński, M. i in. (2017). Global LNG market. Rzeszow-Warsaw: Ignacy Lukasiewicz Energy Policy Institute.

Gonera, J. (2018). Pewna rozbudowa terminalu LNG w Świnoujściu, Szczecin.tvp.pl, 30.06.2018 [Access: 8.12.2018]. Access on the internet: https://szczecin.tvp.p1/37886231/ pewna-rozbudowa-terminalu-lng-w-swinoujsciu.

Jakóbik, W. (2018). Jakóbik: Po co PGNiG trzecia umowa na LNG z USA? (ANALIZA), Biznesalert.pl, 08.11.2018 [Access: 5.01.2019]. Access on the internet: http://biznesalert.pl/pgnigcheniere-umowa-lng-usa-fort-trump.

Januszek, M. (2018). Nowelizacja ustawy ws. inwestycji w gazoporcie: postowie poparli projekt, Inżynieria.com, 05.06.2018 [Access: 17.12.2018]. Access on the internet: https://inzynieria. com/wpis-branzy/wiadomosci/8/52587, nowelizacja-ustawy-ws-inwestycji-w-gazoporcieposlowie-poparli-projekt.

Jędrzejewski, W. (2013). Terminal LNG $w$ Świnoujściu a integracja środkowoeuropejskiego rynku gazu [w:] Piątek, J.J., Podgórzańska, R., red., Terminal LNG w Świnoujściu a bezpieczeństwo energetyczne regionu i Polski. Toruń: Wydawnictwo Adam Marszałek.

Konsumpcja gazu w Polsce rośnie. Spada udziat importu gazu z Rosji, rośnie udziat importu LNG, PGNIG.pl, 03.08.2018 [Access: 10.12.2018]. Access on the internet: http://pgnig.pl/aktualnosci/-/news-list/id/konsumpcja-gazu-w-polsce-rosnie-spada-udzial-importu-gazu-z-rosjirosnie-udzial-importu-lng/newsGroupId/10184. 
Księżopolski, K.M. (2013). Wptyw budowy terminalu LNG w Świnoujściu na bezpieczeństwo ekonomiczne Polski [w:] Piątek, J.J., Podgórzańska, R., red., Terminal LNG w Świnoujściu a bezpieczeństwo energetyczne regionu i Polski. Toruń: Wydawnictwo Adam Marszałek.

Kubiak, K., Janik, W.J., Szulc, T. (2016). Wybrane aspekty wspótczesnego bezpieczeństwa narodowego, Elbląg: Elbląska Uczelnia Humanistyczno-Ekonomiczna.

Luciani, G. (2016). The EU and LNG as a Flexible Tool for Energy Security: Constraints and Opportunities, [w:] Colombo, S., Harrak El M., Sartori N., ed., The Future of Natural Gas Markets and Geopolitics. Lenthe Publishers.

Malinowski, D. (2018). Rozbudowa gazoportu to już tylko kwestia czasu, Gazownictwo.wnp.pl, 23.05.2018 [Access: 7.12.2018]. Access on the internet: https://gazownictwo.wnp.pl/ rozbudowa-gazoportu-to-juz-tylko-kwestia-czasu,323692_1_0_0.html.

Piszczatowska, J., Kadej, L. (2018). Rekordowy czas dla polskiego rynku gazu, Wysokienapięcie.pl, 04.04.2018 [Access: 29.01.2019]. Access on the internet: https://wysokienapiecie.pl/ 9288-rekordowy-czas-dla-polskiego-rynku-gazu-pgnig.

Polskie LNG przygotowuje proces przetargowy dotyczacy rozbudowy terminalu LNG $w$ Świnoujściu, Polskielng.pl 23.11.2018 [Access: 10.12.2018]. Access on the internet: http://www.polskielng.pl/biuro-prasowe/aktualnosci/wiadomosc/artykul/201580.

Prezes polskiego LNG. Rozbudowa gazoportu jest niezbędna, Swinoujskie.info, 09.09.2018, [Access: 3.12.2018]. Access on the internet: http://www.swinoujskie.info/2018/09/09/prezespolskiego-lng-rozbudowa-gazoportu-jest-niezbedna.

Rudnicki, M. (2017). Rozbudowa gazoportu w Świnoujściu za 5 miliardów. A już dziś jest największym na Battyku, [Access: 10.12.2018]. Access on the internet: https://gs24.pl/rozbudowagazoportu-w-swinoujsciu-za-5-miliardow-a-juz-dzis-jest-najwiekszym-na-baltyku/ar/ 12660570 .

Rusza przetarg na rozbudowe terminalu LNG, Wgospodarce.pl, 19.12.2018 [Access: 19.12.2018]. Access on the internet: http://wgospodarce.pl/informacje/57947-rusza-przetarg-narozbudowe-terminalu-lng.

Świątkowska, J. (2013). Rola terminalu LNG w Świnoujściu w budowaniu bezpieczeństwa energetycznego państw Grupy Wyszehradzkiej [w:] Piątek J.J., Podgórzańska R., red., Terminal LNG w Świnoujściu a bezpieczeństwo energetyczne regionu i Polski. Toruń: Wydawnictwo Adam Marszałek.

Terminal LNG $w$ Świnoujściu, Polskie LNG [Access: 5.02.2019]. Access on the internet: http://www.polskielng.pl/lng-terminal/lng-terminal-in-swinoujscie.

Wojcieszak, Ł. (2012). Polska, Ukraina i Białoruś wobec problemu dostaw i tranzytu rosyjskiego gazu, Bielsko-Biała: Wyższa Szkoła Administracji.

Wspólnie na rzecz rozbudowy Terminalu LNG $w$ Świnoujściu, Polskielng.pl, 09.11.2017 [Access: 11.12.2018]. Access on the internet: http://www.polskielng.pl/biuro-prasowe/aktualnosci/ wiadomosc/artykul/201499.

DOI: 10.7862/rz.2019.mmr.16

The text was submitted to the editorial office: March 2019.

The text was accepted for publication: June 2019. 